\title{
A Geospatial Analysis of Ground Water Quality Mapping using GIS in Sangareddy District
}

\author{
Mrs. Soniya Grace \\ Department of Civil Engineering \\ JNTUH College of Engineering Sultanpur
}

\begin{abstract}
Now-a-days ground water has become as essential resource due to an increase of its need for domestic, agricultural and industrial uses etc., consequently ground water quality is very important as its quantity.GIS helps in better understanding of spatial patterns and relations. The present study represents the spatial variability of ground water quality mapping for Sangareddy district, Telangana. The thematic map of groundwater quality parameters, such as pH, TDS, Calcium (Ca), Chloride (Cl), Sulphates $\left(\mathrm{SO}_{4}\right)$, Nitrate $\left(\mathrm{NO}_{3}\right)$, Fluoride $(\mathrm{F})$, Hardness has been tested for all the water samples in order to understand the hydro geochemistry of the groundwater. The results obtained for water quality parameter were compared with standard parameter values suggested by the Bureau of Indian Standards (IS 10500:2012) for drinking water suitability. The spatial contour map of these groundwater quality parameters was derived in Arc Map10.5 software using an Inverse Distance Weighted (IDW) spatial interpolation technique. The study facilitates to understand the existing groundwater quality conditions and to develop appropriate management practices to protect the groundwater sources.
\end{abstract}

Index Terms- Groundwater quality parameters, Arc GIS, spatial contour maps, overlay analysis

\section{INTRODUCTION}

Groundwater is almost globally important for human being consumption as well as for the support of habitat and for maintaining the quality of base flow to rivers. Ground water resources are of high dependence due to its uses for all purposes starting from domestic, agricultural, industrial and commercial. The high dependence resulted in increasing pressure on available ground water resources in terms of quantity and quality. The high withdrawal for industrial and agricultural activities that related to the increase in population and low recharge reduced the amount of available groundwater which contributes significantly to the deterioration in groundwater quality[1].Therefore groundwater quality monitoring has become very essential. Geospatial technology is the latest one available to various thematic data can store, analyze and manipulate for the natural resources management. The existing groundwater quality condition monitoring and management of polluted areas are identified using GIS software. The GIS-based groundwater quality mapping and its suitability evaluation for irrigation and domestic purpose [2], [5],[7]\&[10]. The study area having the issues of environmental pollution due to the dying factories, untreated sewage water released into the river system. The present study has made to prepare the various thematic maps of groundwater quality parameters spatial variation for Sangareddy district using Geospatial Technology.

\section{STUDY AREA}

Sangareddy (formerly Sangareddypeta) is a town and the district headquarters of Sangareddy district the Indian state of Telangana. It was named after the ruler Sanga, who was the son of Rani Shankaramba, a ruler of Medak during the period of Nizams. Sangareddy District is located in the northern region of the Indian state of Telangana. It Lies between $17^{\circ}$ $25^{\prime} 0^{\prime \prime} \mathrm{N}$ to $18^{\circ} 20^{\prime} 0^{\prime \prime} \mathrm{N}$ and $77^{\circ} 25^{\prime} 0^{\prime \prime} \mathrm{E}$ to $78^{\circ} 25^{\prime} 0^{\prime \prime}$ and its area is $4,464.87 \mathrm{~km}^{2}$ with Mandals 26 with Population of 15 , 27,628 and Density 340 per sq.km .The approximate temperature varies from $26{ }^{\circ} \mathrm{C}$ to $79{ }^{\circ} \mathrm{C}$. Singur dam is also located in this district. It is irrigation, hydroelectric and drinking water project located in singooru village

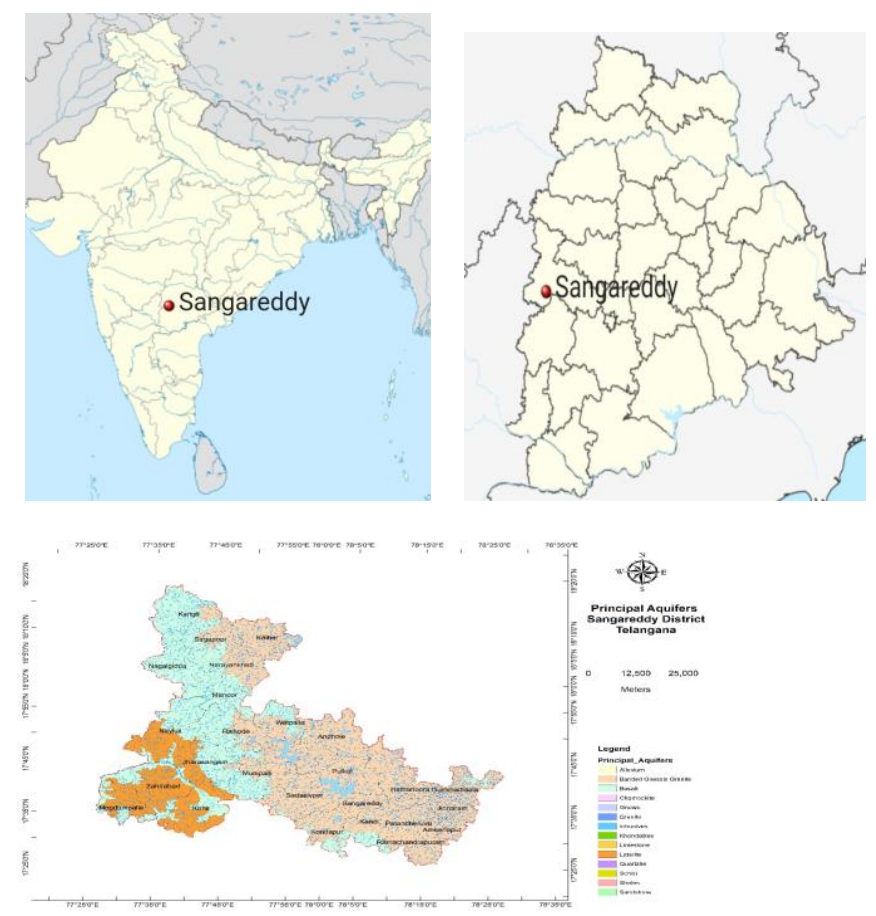

Fig.1.Location map of the study area

\section{METHODOLOGY}

The methodology involves collections of water samples. The water quality database is analyzed and then used as attribute database for the preparation of thematic maps showing distribution of various water quality parameters. The thematic map of groundwater quality parameters, such as $\mathrm{pH}$, TDS, 
Calcium(Ca), Magnesium(Mg), Sodium(Na), Chloride $(\mathrm{Cl})$, Potassium(K), Sulphates $\left(\mathrm{SO}_{4}\right)$, Phosphate $\left(\mathrm{PO}_{4}\right), \mathrm{Nitrate}\left(\mathrm{NO}_{3}\right)$, Fluoride(F), Hardness were used for overlay integration analysis to prepare the groundwater quality map of Sangareddy district using Inverse Distance Weighted(IDW) spatial interpolation technique. Finally the various water quality spatial contour maps were used in GIS for integration analysis to prepare the water quality map.

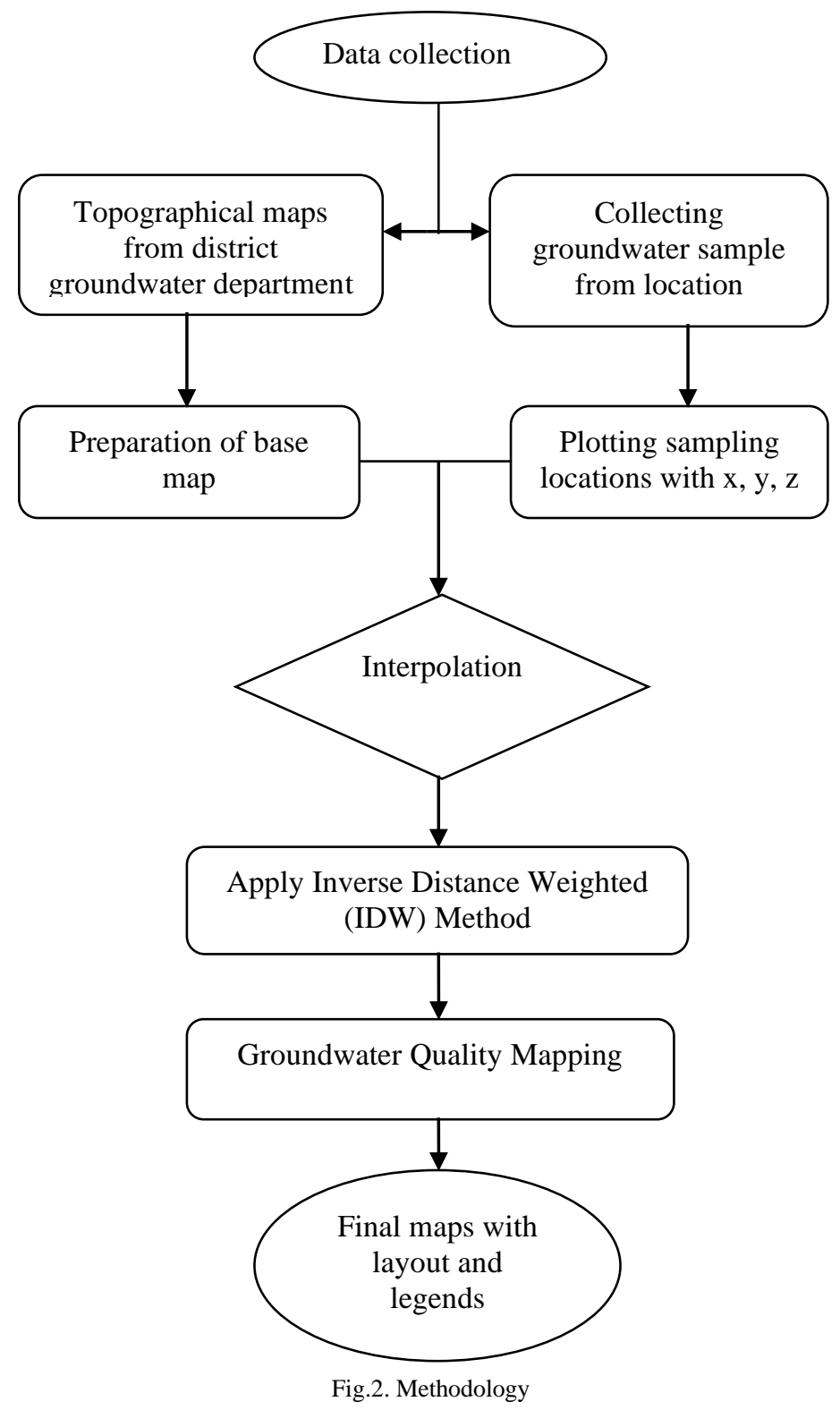

IV RESULTS And DISCUSSION

The spatial and the attribute database generated are integrated for the generation of spatial variation maps of major water quality parameters $\mathrm{pH}$, TDS, $\mathrm{Ca}, \mathrm{Cl}, \mathrm{SO}_{4}, \mathrm{NO}_{3}, \mathrm{~F}$. Groundwater quality maps has been showed below for each parameter. In this study groundwater quality data were prepared using Arc Map 10.5software. This integration of the groundwater quality maps helps us to know the existing groundwater condition in the area

\section{pH}

$\mathrm{pH}$ is a significant parameter in evaluating acidity or alkalinity of water. The computation of $\mathrm{p}^{\mathrm{H}}$ is to determine the intensity or alkalinity and measures the concentration of hydrogen ions. The study area $\mathrm{pH}$ value ranges from 6.45 to 10.41 with an intermediate value of 8.54. As per IS 10500:2021[3] standards the study area $\mathrm{pH}$ value classified into three categories of Good (6.5 to 8.5) and Moderate (8.5 to 9.2) and poor (>9.2) as shown in fig 3. The higher proportion of $\mathrm{pH}$ is by the influence of high biological activity and can also by the uptake of $\mathrm{CO}_{2}$ by photosynthesizing organisms

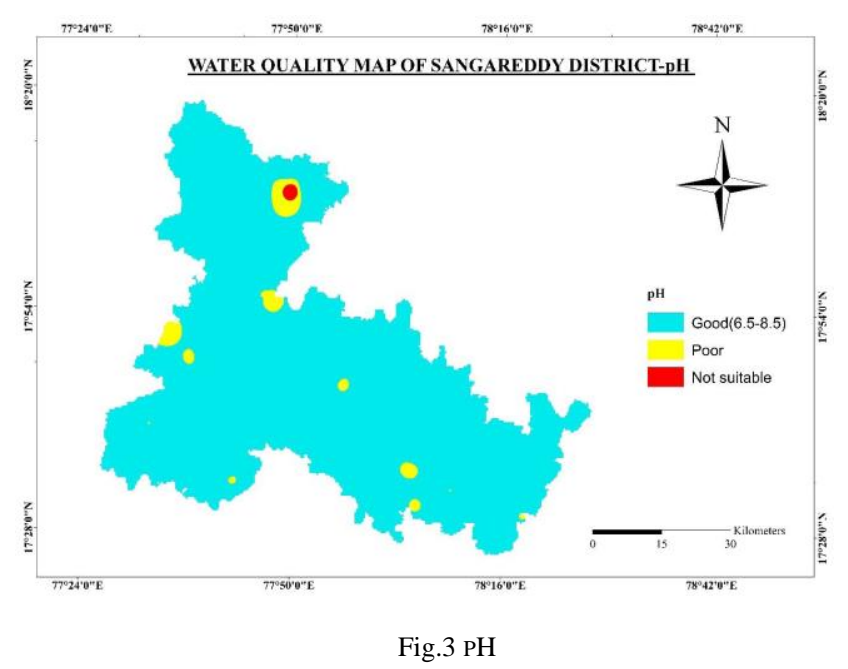

Total dissolved solids (TDS)

The analysis of TDS for study area shows the minimum 102 $\mathrm{mg} / \mathrm{l}$ and the maximum of $8051 \mathrm{mg} / \mathrm{l}$. Further, the understanding of the spatial distribution of interpolation was carried out. The value of TDS divided into 3 major categories Namely Good (<500 mg/l), moderate (500 to $2000 \mathrm{mg} / \mathrm{l}$ ) and Poor (>2000 mg/l) as shown in fig.4. The spatial distribution map shows the major part of the study area is good to moderate. The poor category is observed small part of the district.

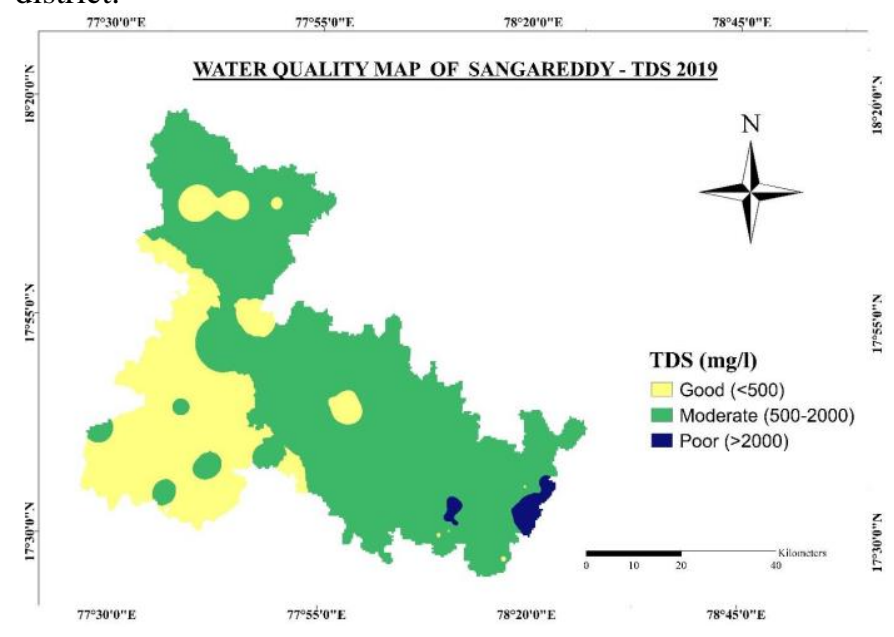

Fig.4 TDS

\section{Calcium}

Calcium is an important constituent in natural water. The concentration of calcium ranges from 8.18 to $669.5 \mathrm{mg} / \mathrm{l}$ 
observed in the study area. The spatial contour map of study area Ca classified into three categories of Good $(<75 \mathrm{mg} / \mathrm{l})$, Moderate ( 75 to $200 \mathrm{mg} / \mathrm{l})$ and Poor (>200 mg/l) as shown in fig. 5 .The Good to moderate amount of calcium was observed throughout the study area due to the influence of industrial and untreated sewage water released into the river / Pond.

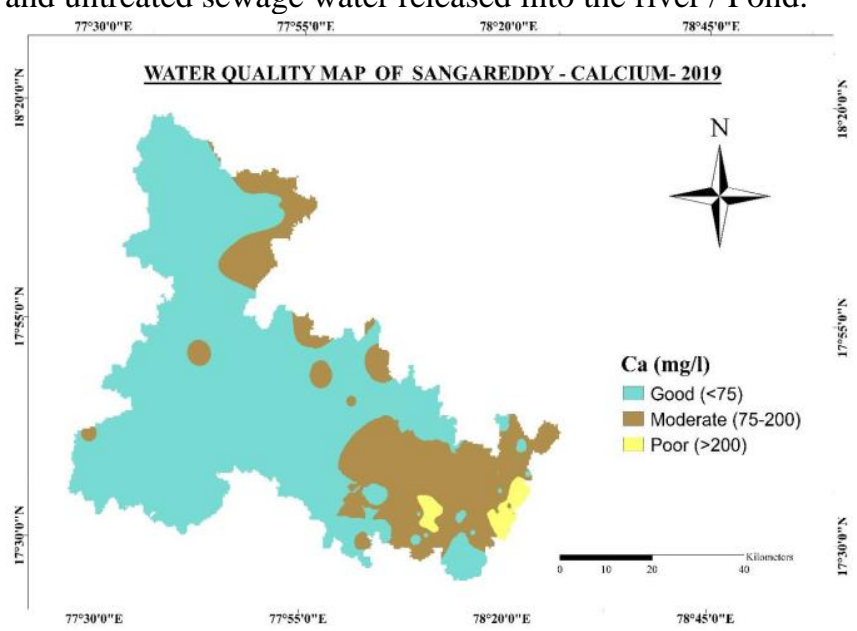

Fig. $5 \mathrm{Ca}$

\section{Chlorides}

The study area, Chloride value varies between 10.8 to 3245.2 $\mathrm{mg} / \mathrm{l}$.From this range Values, the spatial contour map of chloride has been prepared and shown in fig.6. The spatial contour map of study area $\mathrm{Cl}$ classified into three categories Good $(<250 \mathrm{mg} / \mathrm{l})$, moderate $(250$ to $1000 \mathrm{mg} / \mathrm{l})$ and Poor (> $1000 \mathrm{mg} / \mathrm{l})$

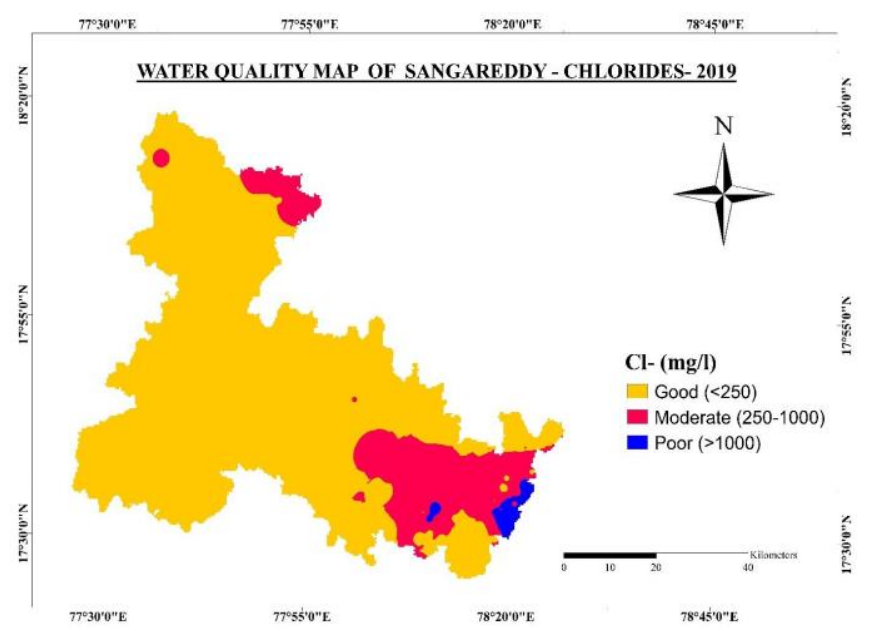

Fig.6 Cl

\section{Sulphate}

Natural water contains sulphate ions and the majority of these ions are also soluble in water. Many sulphate ions are turned out by oxidation process of their ores, and moreover present in industrial wastes. Sulphate is dissolved most important components of the rain. The high concentration of $\mathrm{SO}_{4}$ in drinking water caused the dehydration and diarrhoea. Kids are habitually more sensitive to sulphate than adults. The method of measurement of sulphate quantity is by UV
Spectrometer. As per BIS 10500:2012 the Sulphate desirable and permissible

Limit is $200 \mathrm{mg} / \mathrm{l}$ and $400 \mathrm{mg} / \mathrm{l}$ respectively. The sulphate range varies in the study area between 3.7 to $278.2 \mathrm{mg} / \mathrm{l}$. The spatial study map area of $\mathrm{SO}_{4}$ is shown in fig.7

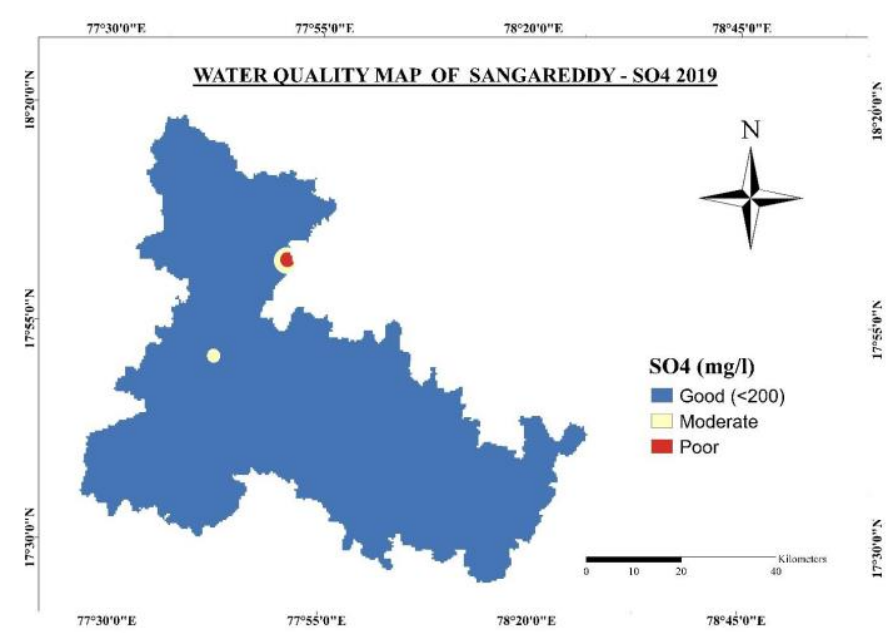

\section{Nitrate}

Fig.7. $\mathrm{SO}_{4}$

Nitrate is one of the most general ground water contaminants in rural areas. It is synchronized in drinking water primarily because surplus level can cause "methemoglobineamia" or "Blue baby" disease. The study area Nitrate concentration is varied from 18.9 to $41.5 \mathrm{mg} / \mathrm{l}$. The spatial contour map of study area Nitrate value is categorized as Good $(<40 \mathrm{mg} / \mathrm{l})$, moderate (40 to $45 \mathrm{mg} / \mathrm{l}$ ) and Poor (>45 mg/l) classes as shown in fig.8. The permissible limit of Nitrate concentration is $45 \mathrm{mg} / \mathrm{l}$ according to BIS 10500:2012.

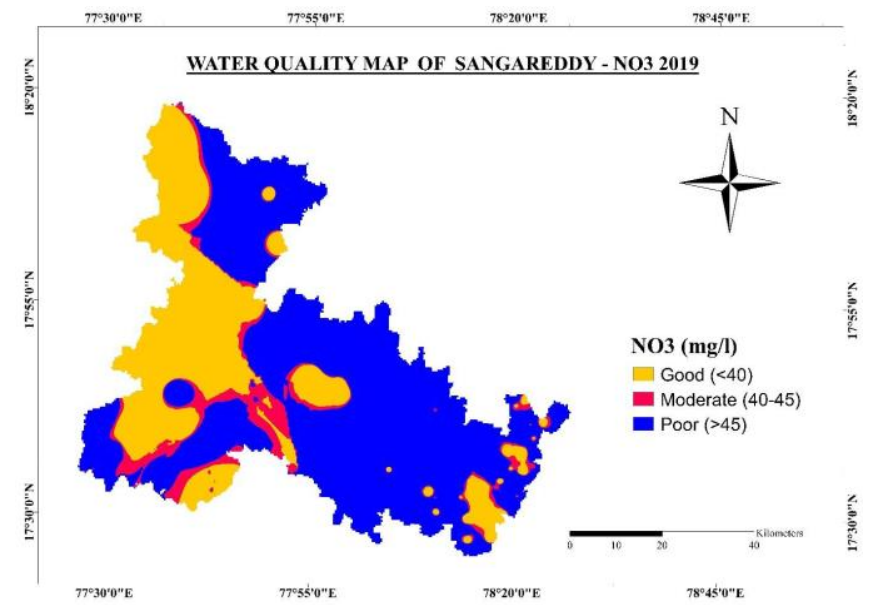

Fig. $8 \mathrm{NO}_{3}$

\section{Fluorine}

Fluoride value in the study area groundwater ranges from 0.53 to $3.99 \mathrm{mg} / \mathrm{l}$ was observed. As per BIS standards, the desirable and permissible limit of drinking water for Fluoride is $1.0 \mathrm{mg} / \mathrm{l}$ and $1.5 \mathrm{mg} / \mathrm{l}$ respectively. The spatial contour map of Fluoride has been prepared and presented as shown in fig. 9 


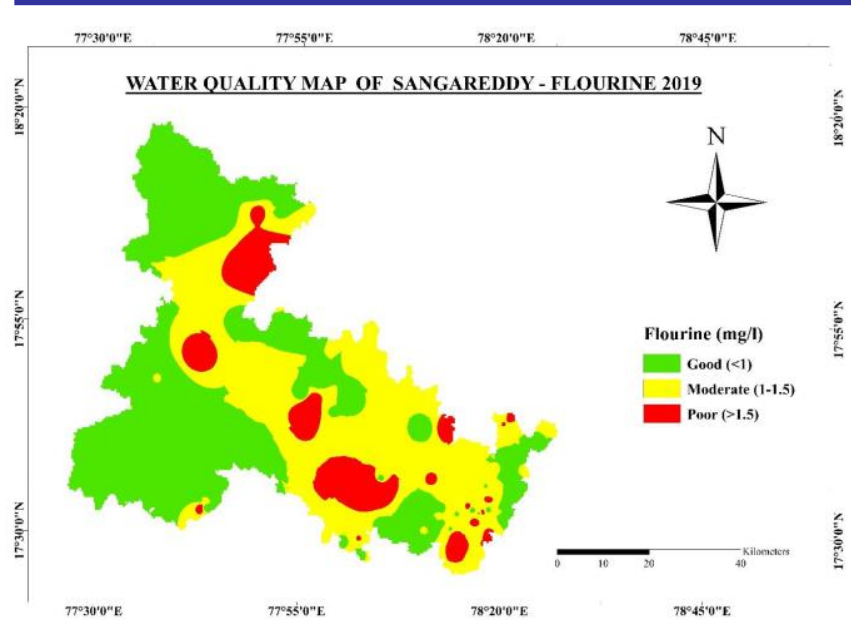

Fig.9. F

\section{Total Hardness}

According to the BIS, the ideal TH for drinking water is below $200 \mathrm{mg} / \mathrm{L}$ and the max permissible limit is $600 \mathrm{mg} / \mathrm{L}$. It is recommended that people with kidney problem should drink pure water having $\mathrm{TH}$ level below $100 \mathrm{mg} / \mathrm{L}$ for better recovery. The spatial contour map of Fluoride has been prepared and presented as shown in fig. 10

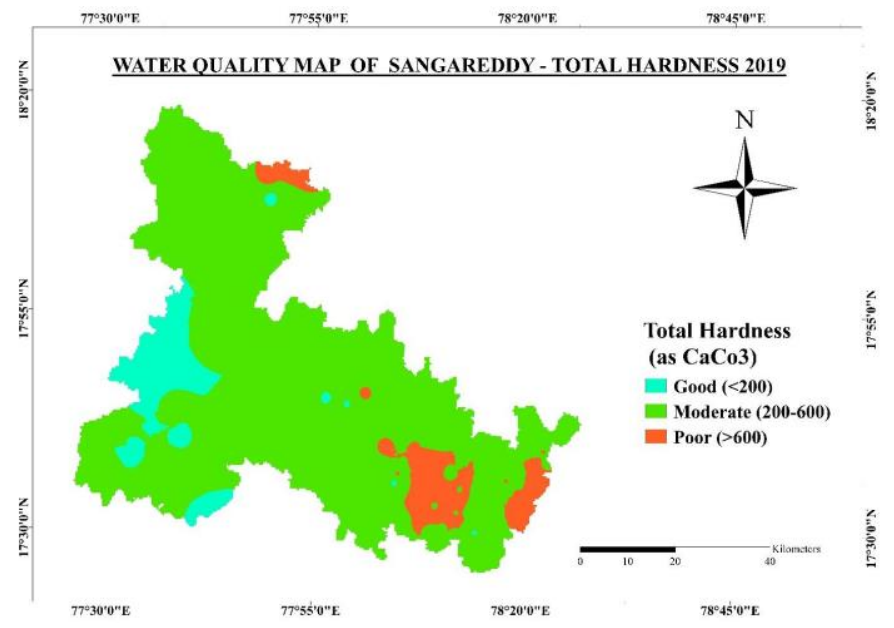

Fig.10 TH

\section{CONCLUSION}

The spatial representation of groundwater quality analysis indicates that the study area needs a few measures of treatment before utilization of groundwater. The study facilitates to understand the existing groundwater quality conditions and to develop appropriate management practices to protect the groundwater sources. The most significant pollutants observed in the present study area are Fluorides and Nitrates needs to be monitored regularly as the map shows where the value is above the desirable limit.Those areas include Narayankhed, Sadasivpet, R. C. puram, Hathnoor and some parts of Naykal, Munipalli, and Patancheru. It can be concluded that the growing population and urbanization,This study indicates that preventive measures should be taken to avoid further rise of fluoride levels in specified areas.The geospatial technology has been useful for groundwater quality mapping as well as the study will be helpful for future planning of groundwater development programme. Use of Integrated Land Information maps is offering value added services like development planning, welfare schemes etc. by maintaining all the records in the prescribed integral digital format in a central repository is possible

\section{REFERENCES}

[1] Piscopo.G. Groundwater Vulnerability map, explanatory notes, Castlereagh catchment, NSW Department of land \& water conservation. (2001)

[2] Sanjay Kumar Goyal, B.S.Choudhary ,GIS based spatial distribution mapping \& suitability evaluation of Groundwater Quality for domestic \& agricultural purpose in kaithal district: Environmental earth Sciences; Springer February (2010)

[3] BIS, Specifications for drinking water, New Delhi: IS 10500.(2012).

[4] APHA Standard methods for the examination of water and waste water $\left(19^{\text {th }}\right.$ edn).Washington :American Public Health Association.(1995)

[5] Balakrishnan, P., Abdhul Saleem., and Mallikarjun, N.D., Groundwater quality mapping using geographic information system (GIS): A case study of Gulburga city, Karnataka, India African Journal of Environmental Science and Technology, vol 5 No.12,pp.1069-1084.( 2011)

[6] Nagarajan, R., Rajmohan, N., Mahendran, U., and Senthamilkumar,S, Evaluation of groundwater quality and its suitability for drinking and agricultural use in Thanjavur city, Tamil Nadu, India, Environmental Monitoring Assessment, DO 10.1007/s10661-009-1279-9.( 2009)

[7] Lo CP, Yeung AKW Concepts and techniques of geographic information systems New Delhi: Prentice-Hall of India Pvt. Ltd, p.492. (2003).

[8] Jeong, C.H... Effect of land use and urbanization on hydrochemistry and contamination of groundwater from Taejon area, Korea. Journal of Hydrology, 253, 194-210. (2001)

[9] WHO (World Health Organization). Guidelines for drinking water quality, $2^{\text {nd }}$ edition, vol 1, 188.(1983)

[10] Sundara Kumar, K., .Assessment and mapping of Groundwater quality using Geographical Information System. International Journal of Engineering Science and technology Vol. 2(11), 2010 , 6035-6046. (2010) 